\title{
THE FEASIBILITY OF GUIDED INQUIRY BASED POWTOON VIDEO MEDIA SUB-MATTER PRESSURE ORGANISM
}

\author{
Inggriani, Kurnia Ningsih, Andi Besse Tenriawaru* \\ Program Studi Pendidikan Biologi, Fakultas Matematika dan Ilmu Pengetahuan Alam \\ Universitas Tanjungpura \\ Jalan Prof. Dr. H. Nawawi, Kota Pontianak 78124 \\ *andibessetenriawaru@ fkip.untan.ac.id
}

Doi: https://doi.org/10.31943/mangiferaedu. v6i.123

Received: February 20, 2021 Accepted: Mey 12, $2021 \quad$ Published: July 31, 2021

Citation: Inggriani., Ningsih, K., \& Tenriawaru, A.B. (2021). The Feasibility of Guided Inquiry Based Powtoon Video Media Sub-Matter Pressure Organism. Jurnal Mangifera Edu, 6(1), 1-19.

\begin{abstract}
This research aims to determine the feasibility of a video powtoon learning media application based on guided inquiry submater application of the concept of substance pressure in organism as a learning media for students and to find responses by students to the powtoon video media. This research is Research and Development (R\&D) research with the Borg and Gall development model which consists of ten stages, this research has only reached the seventh stage which includes potentials and problems, data collection, product design, product validation, design revisions, product trials, and product revisions. The instruments used were the media validation sheet and the student response questionnaire validation sheet which was validated by 5 validators and the student response questionnaire. The subjects were students of class XI SMP Negeri 3 Pontianak. The validation results obtained CVR and CVI values, namely 1 which has met the minimum limit of 0.99 so that it is declared valid. The product trial obtained an overall average score for aspects (cognition, affection, conation) which was $83,57 \%$ so it is categorized as very strong. It can be concluded that the powtoon video media based on guided inquiry sub material is suitable for use as a learning medium.
\end{abstract}

Keywords : Guided inquiry, Powtoon, Substance pressure organism 
Jurnal Mangifera Edu, Volume 6, Issue 1, July 2021, 1-19

\section{ABSTRAK}

Penelitian ini bertujuan untuk mengetahui kelayakan media pembelajaran video powtoon berbasis inkuiri terbimbing submateri aplikasi konsep tekanan zat pada makhluk hidup sebagai media pembelajaran siswa dan untuk mengetahui respon siswa terhadap media video powtoon. Penelitian ini merupakan penelitian Research and Development $(R \& D)$ dengan model pengembangan Borg and Gall yang terdiri dari sepuluh tahapan, penelitian ini hanya sampai pada tahap ke tujuh yang meliputi potensi dan masalah, pengumpulan data, desain produk, validasi produk, revisi desain, uji coba produk dan revisi produk. Instrumen yang digunakan dalam penelitian ini adalah lembar validasi media serta lembar validasi angket respon siswa, yang divalidasi oleh 5 orang validator dan angket respon siswa. Subjek penelitian ini yaitu siswa kelas XI SMP Negeri 3 Pontianak. Hasil validasi dianalisis dengan menggunakan rumus Lawshe pada media video powtoon dan angket respon memperoleh nilai CVR dan CVI yaitu 1 yang telah memenuhi batas minimum yaitu 0,99 sehingga dinyatakan valid. Uji coba produk memperoleh nilai rata-rata secara keseluruhan untuk aspek (kognisi, afeksi, konasi) yaitu sebesar 83,57\% sehingga dikategorikan sangat kuat. Dapat disimpulkan bahwa media video powtoon berbasis inkuiri layak digunakan sebagai media pembelajaran.

Kata kunci: Inkuiri terbimbing, Powtoon, Tekanan zat pada makhluk hidup

\section{PENDAHULUAN}

Iswatun et al., (2017), berdasarkan Lampiran Permendiknas No 22 Tahun 2006 mata pelajaran IPA berkaitan dengan cara mencari tahu tentang alam secara sistematis, sehingga IPA bukan hanya penguasan kumpulan pengetahuan yang berupa fakta-fakta, konsep-konsep, atau prinsip-prinsip saja tetapi juga proses penemuan (inquiry). (Anggareni et al., 2013), juga mengatakan bahwa kurikulum IPA SMP lebih mengarahkan pada pengalaman pembelajaran langsung kepada siswa dalam mempelajari peristiwa yang terjadi di lingkungan sekitar. Proses pembelajaran IPA merupakan perpaduan dari berbagai konsep fisika, kimia, biologi dan bumi antariksa lebih berpotensi untuk mengembangkan pengalaman dan kompetensi siswa untuk memahami alam sekitar (Listiyawati, 2012).

Santrock (dalam Sugiman et al., 2016), keberhasilan dalam proses pembelajaran sangat mempengaruhi perkembangan siswa meliputi perkembangan fisik, emosi, kepribadian, sosial, moral dan intelektual karena siswa SMP merupakan usia remaja awal. Sependapat dengan hal tersebut Irmayanti (2019), menyatakan bahwa siswa SMP pada umumnya berusia antara 13-15 tahun atau secara psikologis berada pada masa remaja awal. Perkembangan intelektual siswa 
pada masa remaja awal berada pada tahap operasional formal, yaitu siswa mampu mengembangkan pikirannya secara lebih realistis/logis dan mampu mengambil makna terhadap pemecahan berbagai persoalan yang mereka alami Piaget (dalam Ali \& Asrori, 2008).

Berdasarkan hasil observasi yang telah dilakukan bahwa dalam proses pembelajarn guru di sekolah menggunakan media antara lain papan tulis, spidol dan powerpoint untuk menyampaikan materi. Pada sub materi aplikasi konsep tekanan zat pada makhluk hidup siswa cenderung kurang memahami konsep tersebut, dikarenakan materi yang bersifat sangat abstrak atau tidak dapat dilihat secara nyata maupun disentuh. Keberhasilan suatu pembelajaran dapat dilihat dari pemahaman materi oleh siswa. Pemahaman materi yang diperoleh siswa dapat dipengaruhi oleh proses belajar. Proses belajar itu sendiri dapat dipengaruhi oleh pemilihan media maupun model pembelajaran yang tepat.

Arsyad (2013) media dalam proses belajar mengajar cenderung diartikan sebagai alatalat grafis, photografis, atau elektronis untuk menangkap, memproses, dan menyusun kembali informasi visual atau verbal. Sementara itu Suhendra et al., (2018) menyatakan bahwa satu diantara beberapa jenis media pembelajaran audio-visual yang dapat digunakan dalam proses pembelajaran adalah powtoon, dan kegiatan pembelajaran dengan menggunakan model inkuiri terbimbing diperlukan adanya media pembelajaran, dengan adanya media pembelajaran akan mempermudah guru untuk menyampaikan materi serta mempermudah peserta didik dalam memahami materi (Sudjana \& Rivai, 2013).

Delviana (2017) dalam dua tahun terakhir salah satu aplikasi video animasi yang telah dikenal dalam dunia pendidikan dan mulai sering digunakan sebagai media pembelajaran adalah aplikasi powtoon. Sementara itu Marlena et al., (2018), menyatakan bahwa aplikasi powtoon merupakan aplikasi yang dapat membuat video animasi secara sederhana, bisa mempresentasikan materi dengan cara yang lebih variatif, unik, dan menyenangkan sesuai dengan tingkat imajinasi, daya komunikasi, substansi, dan kreasi dari guru. Fitur animasi berupa tulisan tangan, animasi kartun, dan efek transisi yang lebih hidup serta pengaturan time line yang sangat mudah, hampir semua fitur dapat diakses dalam satu layar dan mudah digunkan dalam proses pembuatan sebuah paparan (Purwanti \& Suryani, 2018). 
Hal itu semakin terbukti dengan beberapa penelitian yang telah dilakukan oleh Syafitri et al., (2019), berdasarkan validasi media yang dilakukan oleh dua orang dosen diperoleh data rata-rata $85 \%$ dan media yang dikatakan sangat valid. Penelitian lainnya juga dilakukan oleh Puspitarini et al., (2018), dapat disimpulkan bahwa berdasarkan hasil validasi oleh ahli media dan ahli materi, tiga orang siswa dalam uji coba satu persatu, sembilan orang siswa dalam uji coba kelompok kecil menunjukkan bahwa media video powtoon yang dikembangkan layak digunakan. Video pembelajaran dengan topik powtoon berbasis kerja dan tenaga untuk mendukung pembelajaran Flipped Classroom bagi siswa SMA kelas X dinyatakan layak untuk digunakan sebagai media pembelajaran fisika berdasarkan penelitian dari (Herawati et al., 2019).

Hamdayama (2014), secara umum proses pembelajaran dengan menggunakan model pembelajaran inkuiri terbimbing terdiri dari langkah-langkah sebagai berikut yaitu orientasi, merumuskan masalah, membuat hipotesis, mengumpulkan data, menguji hipotesis, menarik kesimpulan. Sementara itu Mulyana et al., (2018), model pembelajaran inkuiri terbimbing memberikan kesempatan kepada siswa untuk belajar bagaimana menemukan fakta, konsep dan prinsip melalui pengalamannya secara langsung. Model inkuiri terbimbing merupakan model pembelajaran yang dapat memfasilitasi siswa untuk membangkitkan rasa ingin tahu, berpikir ilmiah, mampu melakukan investigasi, dan menimba ilmu dengan menentukan diri di bawah bimbingan guru (Haryadi \& Pujiastuti, 2020).

Wulanningsih et al., (2012), model pembelajaran inkuiri terbimbing merupakan pembelajaran yang berpusat pada siswa. Sementara itu Khoirul Anam (dalam Diyantini et al., 2017), menyatakan bahwa dalam pembelajaran inkuiri terbimbing siswa bekerja (bukan hanya duduk mendengarkan lalu menulis) untuk menemukan jawaban terhadap masalah yang dikemukakan oleh guru di bawah bimbingan guru. Model pembelajaran inkuiri terbimbing yang menekankan pada proses penemuan sebuah konsep sehingga muncul sikap ilmiah pada diri siswa (Dewi et al., 2013).

Hal ini sejalan dengan hasil penelitian yang dilakukan oleh Wardani et al,, (2016), dapat disumpulkan bahwa model pembelajaran inkuiri terbimbing efektif dalam meningkatkan karakter siswa. Penelitian lainnya juga dilakukan oleh Almuntasheri et al., (2016), dapat 
Jurnal Mangifera Edu, Volume 6, Issue 1, July 2021, 1-19

disimpulkan bahwa siswa yang diberi perlakuan secara inkuiri terbimbing mencapai nilai yang lebih tinggi secara signifikan jika dibandingkan dengan teman sebayanya dalam kondisi diarahkan guru. Berikutnya hasil dari temuan yang lain juga menunjukkan bahwa pemetaan konsep dengan metode inkuiri terbimbing merupakan strategi pengajaran yang dapat meningkatkan prestasi siswa pada pembelajaran kimia (Jack, 2013).

Penelitian ini bertujuan untuk mengetahui kelayakan media video powtoon berbasis inkuiri sub materi aplikasi konsep tekanan zat pada makhluk hidup dan untuk mengetahui bagaimana respon siswa terhadap media video powtoon berbasisi inkuiri terbimbing sub materi aplikasi konsep tekanan zat pada makhluk hidup. Sehingga dapat menghasilkan suatu produk dalam bentuk media pembelajaran video powtoon berbasis inkuiri terbimbing untuk membantu guru dalam menjelaskan materi tersebut.

\section{METODELOGI PENELITIAN}

Penelitian ini dilaksanakan menggunakan metode penelitian dan pengembangan atau Research and Development (R\&D) dengan model Borg \& Gall (1989). Menurut Sugiyono (2017) menyatakan bahwa R\&D adalah metode penelitian yang digunakan untuk menghasilkan produk tertentu dan menguji keefektifan produk tersebut. Model Borg \& Gall terdiri dari 10 tahapan. Namun pada penelitian ini hanya dilaksanakan hingga tahap ke-7 yaitu potensi dan masalah, pengumupulan data, desain produk, validasi desain, revisi desain, uji coba produk, revisi produk. Subjek pada penelitian ini adalah dua orang dosen ahli dari Program Studi Pendidikan Biologi FKIP Untan dan tiga orang guru mata pelajaran IPA di SMP Negeri tiga Pontianak sebagai validator dan siswa SMP Negeri 3 Pontianak sebagai uji coba terbatas.

Instrumen yang digunakan pada penelitian ini antara lain 1) Lembar validasi media video powtoon berbasis inkuiri terbimbing menurut ahli materi yang terdiri dari tiga aspek yaitu format, isi, dan bahasa. 2) Lembar validasi media video powtoon berbasis inkuiri terbimbing menurut ahli media yang terdiri dari empat aspek yaitu kesederhanaan, ilustrasi, kualitas dan tampilan media, daya tarik 3) Lembar validasi angket respon siswa yang terdiri dari enam aspek yaitu kejelasan, ketepatan, relevansi, kevalidan isi, tidak ada bias, ketepatan bahasa 4) Angket respon siswa meliputi tiga aspek yaitu kognitif, afektif, dan konatif. Angket respon siswa 
menggunakan skala likert dengan empat skala penilaian (kriteria) yaitu SS (Sangat Setuju), S (Setuju), TS (Tidak Setuju), STS (Sangat Tidak Setuju) (Sugiyono, 2017).

Pada penelitian ini analisis data berdasarkan lembar validasi ahli materi dan ahli media sebanyak lima orang validator. Hasil validasi dianalisis menggunakan Content Validity Ratio (CVR) menurut Lawshe (1975), dengan rumus sebagai berikut:

$$
\mathrm{CVR}=\frac{n_{e}-\frac{1}{2} \mathrm{~N}}{\frac{1}{2} \mathrm{~N}}
$$

Keterangan:

CVR : Jumlah validitas isi

$\mathrm{n}_{\mathrm{e}} \quad$ : Jumlah validator yang menyatakan setuju dengan kevalidan media (dianggap setuju jika nilai setiap aspek dengan kisaran rata-rata tiap aspek 3,00-4,00, jika $<3,00$ maka dianggap tidak setuju dengan kevalidan media)

$\mathrm{N} \quad$ : Jumlah validator seluruhnya

Setelah didapatkan nilai CVR, kemudian dihitung nilai CVI (Content Validity Index) untuk menggambarkan bahwa secara keseluruhan butir-butir instrumen memiliki validitas isi yang baik. Adapun rumus CVI adalah sebagai berikut:

$$
\mathrm{CVI}=\frac{C V R}{\text { jumlah item seluruh aspek }}
$$

(Lawshe, 1975).

Jika jumlah validator lima orang maka batas minimum CVR dan CVI $=0,99$. Untuk angket respon siswa dengan menghitung presentasi skor tiap item pertanyaan dengan menggunakan rumus sebagai berikut :

$$
\text { Persentase }=\frac{\text { skor item pertanyaan } / \text { pertanyaan }}{\text { skor tertinggi item pertanyaan } / \text { pertanyaan }} \times 100 \%
$$

Kemudian menentukan kriteria atau kategori respon tanggapan yang diberikan siswa terhadap media video powtoon berbasis inkuiri terbimbing dengan interpretasi berikut:

1. Angka $0 \%-20,99 \%=$ Sangat Lemah

2. Angka $21 \%-40,99 \%=$ Lemah

3. Angka $41 \%-60,99 \%=$ Cukup

4. Angka $61 \%-80,99 \%=$ Kuat 
5. Angka $81 \%-100 \%=$ Sangat Kuat

(Riduwan, 2015).

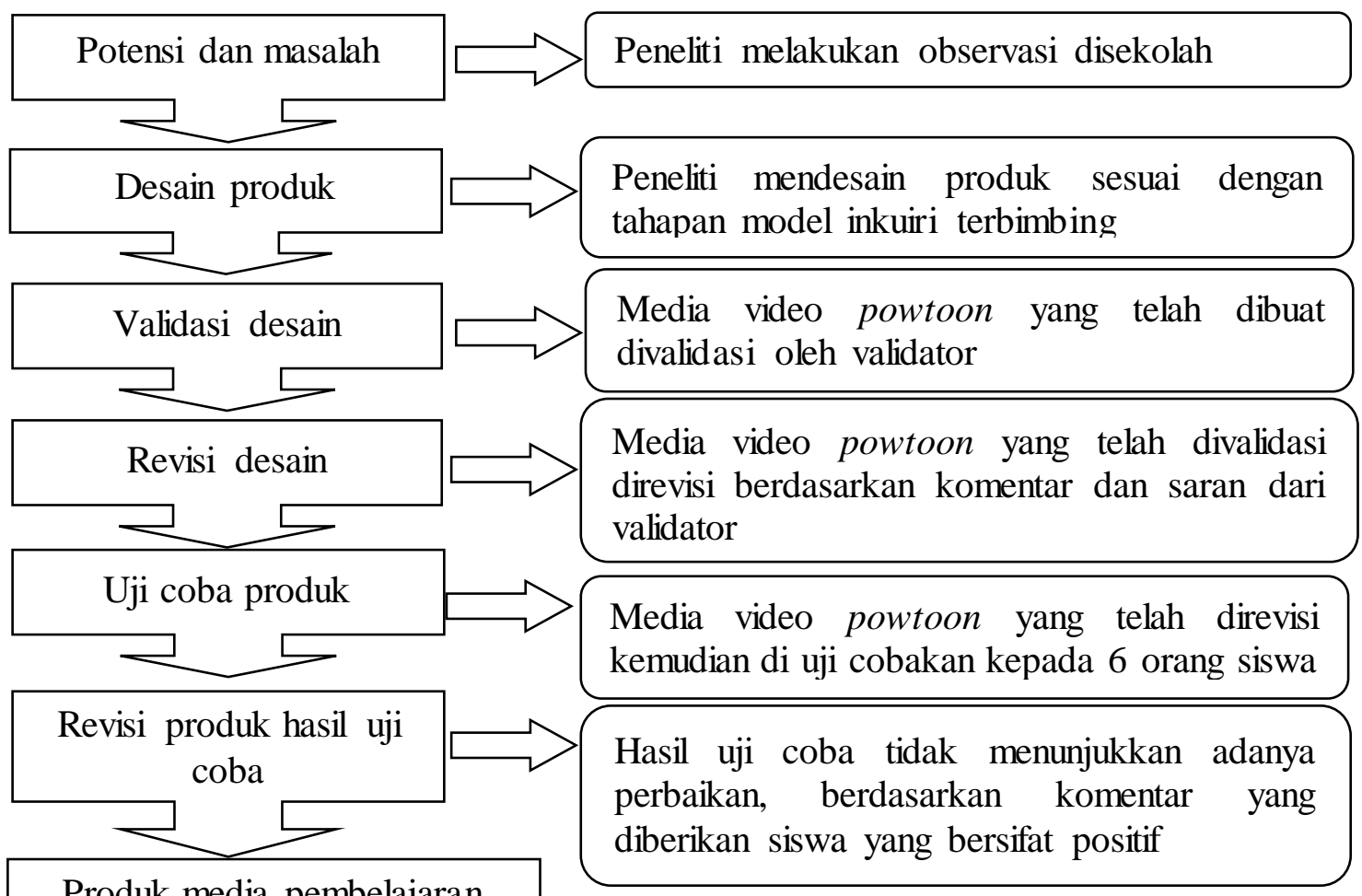

Produk media pembelajaran video powtoon berbasis inkuiri terbimbing sub materi aplikasi konsep tekanan zat pada makhluk hidup

Gambar 1. Bagan prosedur pelaksanaan penelitian

\section{HASIL DAN PEMBAHASAN}

Penelitian ini menggunakan metode penelitian dan pengembangan atau Research and Development (R\&D) dengan model Borg \& Gall (1989). Model Borg and Gall terdiri dari 10 tahapan. Namun pada penelitian ini hanya dilaksanakan hingga tahap ke 7 yaitu potensi dan masalah, pengumupulan data, desain produk, validasi desain, revisi desain, uji coba produk, revisi produk.

Pada tahap pertama yaitu potensi dan masalah pada tahapan ini dilakukan observasi dan wawancara dengan guru di sekolah terkait dengan proses pembelajaran, media pembelajaran https://jurnal.biounwir.ac.id/index.php/mangiferaedu | 7 
yang digunakan serta kendala yang dihadapi oleh guru dalam menyampaikan materi di sekolah. (Fatoni \& Abdurrahman, 2006 dalam Saihu, 2019). Observasi yaitu metode pengumulan data yang digunakan dengan cara mengamati serta mencatat hal-hal sesuai dengan keadaan pada lokasi atau tempat yang menjadi objek penelitian, sedangkan wawancara adalah teknik pengumpulan data melalui proses tanya jawab lisan yang berlangsung satu arah, artinya pertanyaan diberikan oleh satu orang dan ditujukan untuk narasumber. Sedangkan menurut Sugiyono (2015), observasi merupakan suatu kegiatan pemantauan dari suatu yang menjadi objek penelitian. Wawancara merupakan suatu dialog yang dilakukan oleh pewawancara untuk memperoleh informasi seseorang yang diwawancara (narasumber) (Arikunto, 2013).

Berdasarkan hasil observasi dan wawancara yang telah dilakukan diperoleh informasi bahwa guru di sekolah sering menggunakan model pembelajaran discovery learning, menggunakan media pembelajaran seperti powerpoint, sehingga akan dikembangkan menjadi media video powtoon berbasis inkuiri terbimbing.

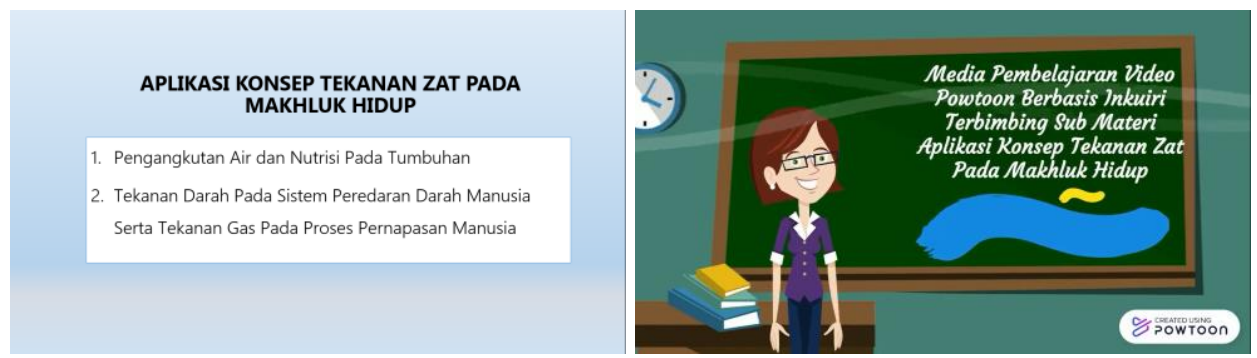

Gambar 2. (a) Media yang digunakan guru (b) Media yang dikembangkan

Tahap kedua yaitu pengumpulan data pada tahap ini dilakukan pengumpulan data dilakukan pengumpulkan data terkait dengan media yang digunakan guru, model pembelajaran yang digunakan guru pada saat proses pembelajaran dan hasil belajar siswa pada semester ganjil yang terdiri dari beberapa materi pelajran IPA Biologi diantaranya tekanan zat dan penerapannya dalam kehidupan sehari-hari, sistem pernapasan manusia dan sistem ekskresi manusia. Pada meteri tekanan zat dan penerapannya dalam kehidupan sehari-hari materi dibagi menjadi dua sub materi yaitu materi tekanan zat untuk IPA (fisika) dan aplikasi konsep tekanan zat pada makhluk hidup untuk IPA (biologi). Selanjutnya dilakukan analisis data terhadap hasil ulangan harian bahwa diketahui nilai pada ulangan harian submateri aplikasi konsep tekanan zat https://jurnal.biounwir.ac.id/index.php/mangiferaedu | 8 
Jurnal Mangifera Edu, Volume 6, Issue 1, July 2021, 1-19

pada makhluk hidup yaitu IPA biologi mendapatkan nilai dibawah kriteria ketuntasan minimum $\operatorname{KKM}(<80)$.

Tahap yang ketiga yaitu desain produk pada tahapan ini dilakukan desain produk untuk membuat sebuah video powtoon berbasis inkuiri terbimbing berdasarkan kompetensi dasar, indikator, tujuan pembelajaran, materi pembelajaran serta dilengkapi dengan langkah-langkah dalam model pembelajaran inkuiri terbimbing yaitu orientasi, merumuskan masalah, membuat hipotesis, mengumpulkan data, menguji hipotesis, menarik kesimpulan (Hamdayama, 2014).

Tahap yang keempat yaitu validasi desain pada tahap ini media video powtoon berbasis inkuri terbimbing yang telah dibuat divalidasi oleh validator. Tahap validasi melibatkan lima orang validator diantaranya dua orang dosen dan tiga orang guru mata pelajan IPA dengan menggunakan instrumen lembar validasi ahli materi, lembar validasi ahli media dan lembar validasi angket respon siswa. Analisis lembar validasi menggunakan rumus Lawshe (1975) untuk lima orang validator dengan nilai minimum CVI (Content Validity Index) yaitu 0,99 sehingga dikategorikan valid. Berikut hasil validasi oleh 5 orang validator ahli materi terhadap media video powtoon berbasis inkuiri terbimbing menggunakan rumus Lawshe (1975).

\section{Tabel 1. Hasil validasi oleh ahli materi}

\begin{tabular}{|c|c|c|c|c|c|c|c|c|}
\hline \multirow[b]{2}{*}{ Aspek } & \multirow[b]{2}{*}{ Kriteria } & \multicolumn{5}{|c|}{ Validator ke- } & \multirow[b]{2}{*}{ CVR } & \multirow[b]{2}{*}{ Ket } \\
\hline & & 1 & 2 & 3 & 4 & 5 & & \\
\hline \multirow[t]{2}{*}{ Format } & $\begin{array}{l}\text { Keserasian warna, tulisan, dan gambar pada media video } \\
\text { powtoon }\end{array}$ & 4 & 3 & 4 & 4 & 4 & 1 & Valid \\
\hline & $\begin{array}{l}\text { Kesederhanaan uraian materi yang disajikan dalam media } \\
\text { video powtoon }\end{array}$ & 4 & 3 & 4 & 4 & 4 & 1 & Valid \\
\hline \multirow[t]{5}{*}{ Isi } & $\begin{array}{l}\text { Media video powtoon yang digunakan sesuai dengan tujuan } \\
\text { pembelajaran }\end{array}$ & 3 & 4 & 4 & 4 & 4 & 1 & Valid \\
\hline & Media video powtoon sesuai dengan materi pembelajaran & 3 & 3 & 4 & 4 & 4 & 1 & Valid \\
\hline & Kelengkapan uraian materi & 3 & 3 & 3 & 3 & 3 & 1 & Valid \\
\hline & Keakuratan konsep dan definisi & 3 & 3 & 3 & 3 & 3 & 1 & Valid \\
\hline & Kemudahan dalam memahami uraian materi yang disajikan & 3 & 3 & 4 & 4 & 4 & 1 & Valid \\
\hline \multirow[t]{3}{*}{ Bahasa } & Bahasa yang digunakan mudah dipahami & 4 & 4 & 4 & 4 & 4 & 1 & Valid \\
\hline & Bahasa yang digunakan sesuai dengan jenjang pendidikan & 4 & 4 & 4 & 4 & 4 & 1 & Valid \\
\hline & Kesesuaian dengan Kaidah Bahasa Indonesia & 4 & 4 & 4 & 4 & 4 & 1 & Valid \\
\hline CVI & & & & & & & 1 & \\
\hline
\end{tabular}

Ket :

$\mathrm{CVR}=$ Content Validity Ratio

$\mathrm{CVI}=$ Content Validity Index 
Jurnal Mangifera Edu, Volume 6, Issue 1, July 2021, 1-19

Selain validasi oleh ahli materi, instrumen pada penelitian ini juga terdapat lembar validasi ahli media berikut hasil validasi oleh lima orang validator ahli media terhadap media video powtoon berbasis inkuiri terbimbing menggunakan rumus Lawshe (1975).

Table 2. Hasil validasi oleh ahli me dia

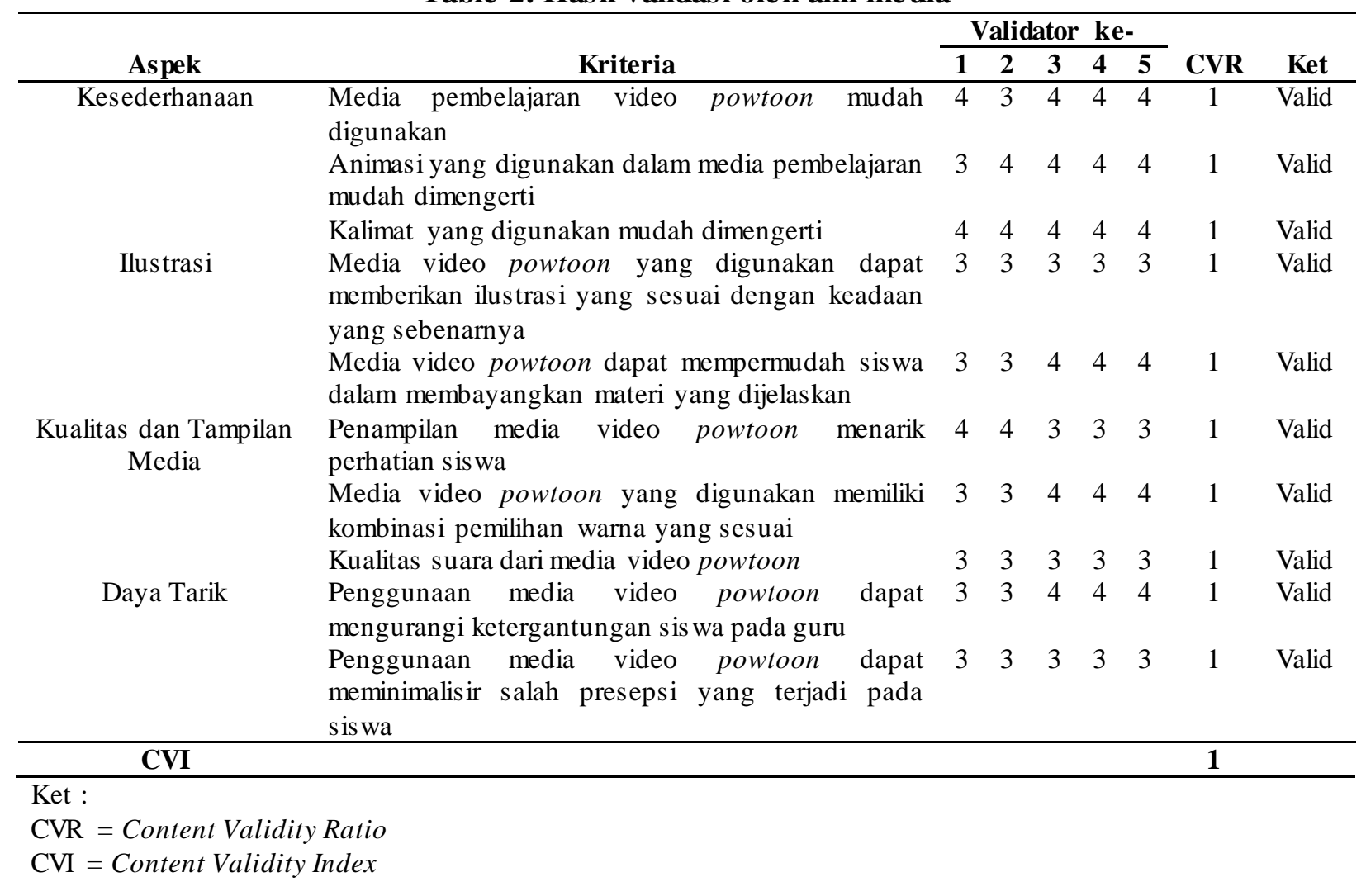

Berdasarkan hasil validasi terhadap media video powtoon berbasis inkuiri terbimbing pada tabel 1 lembar validari ahli materi dan tabel 2 lembar validasi ahli media, diperoleh nilai CVR dan CVI yaitu 1, sehingga media pembelajaran video powtoon berbasis inkuiri terbimbing dinyatakan layak digunakan sebagai media pembelajaran siswa kelas VIII SMP karena telah memenuhi batas minimum Lawshe untuk 5 orang validator adalah 0,99.

Berdasarkan lembar validasi ahli materi jika dilihat aspek isi dengan kriteria kelengkapan materi dan keakuratan uraian dan definisi mendapatkan rata-rata skor 3 ini termasuk dalam kategori baik namun perlu adanya perbaikan pada tampilan materi media video powtoon. Berdasarkan komentar dan saran yang diberikan oleh validator ahli materi bahwa 
sebaiknya menampikan perbedaan secara morfologi tumbuhan monokotil dan dikotil. Oleh karena itu, ada tampilan yang diperbaiki seperti pada gambar berikut.

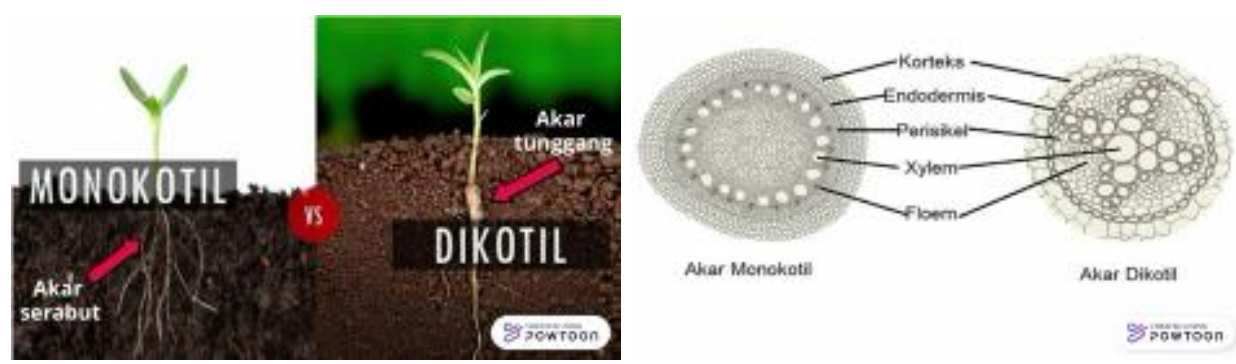

Gambar 3. (a) Sebelum revisi (b) Setelah revisi

Berdasarkan lembar validasi ahli media jika dilihat aspek ilustrasi dengan kriteria media video powtoon yang digunakan dapat memberikan ilustrasi yang sesuai dengan keadaan yang sebenarnya mendapatkan rata-rata skor 3 ini termasuk dalam kategori baik namun perlu adanya perbaikan pada tampilan ilustrasi media video powtoon. Berdasarkan komentar dan saran yang diberikan oleh validator ahli media bahwa apersepsi sebaiknya memperhatikan variasi aktivitas seperti duduk atau berdiri, maupun berjalan dan kemudian merasakan denyut nadi. Oleh karena itu, ada tampilan yang diperbaiki seperti pada gambar berikut.
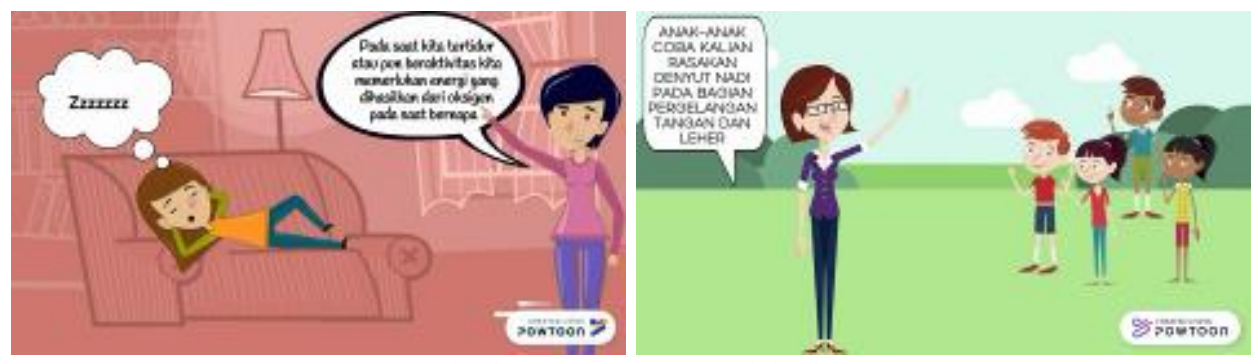

Gambar 4. (a) Sebelum revisi (b) Setelah revisi

Selain itu validator ahli media juga memberikan komentar dan saran bahwa percobaan tidak tepat sasaran lebih baik disesuaikan dengan level siswa SMP, sebaiknya cukup hanya dengan mengenalkan beberapa alat pengukur tekanan darah. Oleh karena itu, ada tampilan yang diperbaiki seperti pada gambar berikut. 

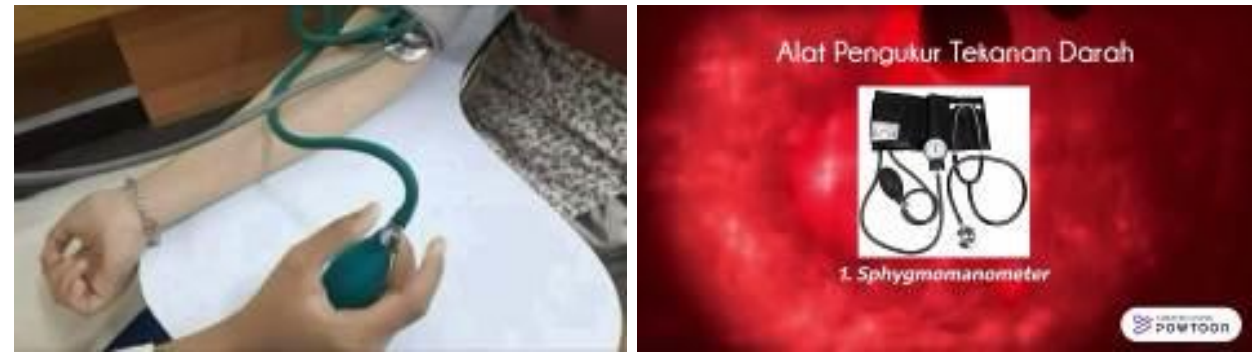

Gambar 5. (a) Se belum revisi (b) Setelah revisi

Selain validasi media pembelajaran video powtoon juga dilakukan validasi angket respon siswa. Berikut adalah hasil validasi angket respon siswa.

Tabel 3. Hasil validasi angket respon sis wa

\begin{tabular}{|c|c|c|c|c|c|c|c|c|}
\hline \multirow[b]{2}{*}{ Aspek } & \multirow[b]{2}{*}{ Indikator } & \multicolumn{5}{|c|}{ Validator ke- } & \multirow[b]{2}{*}{ CVR } & \multirow[b]{2}{*}{ Ket } \\
\hline & & 1 & 2 & 3 & 4 & 5 & & \\
\hline \multirow{3}{*}{ Kejelas an } & Kejelasan judul lembar angket & 4 & 4 & 4 & 4 & 4 & 1 & Valid \\
\hline & Kejelasan butir pernyataan & 3 & 4 & 4 & 4 & 4 & 1 & Valid \\
\hline & Kejelasan petunjuk pengisian angket & 4 & 3 & 4 & 4 & 4 & 1 & Valid \\
\hline Ketepatan & Ketepatan pernyataan dengan jawaban yang diharapkan & 3 & 3 & 3 & 3 & 3 & 1 & Valid \\
\hline \multirow{2}{*}{ Relevansi } & Pernyataan berkaitan dengan tujuan penelitian & 4 & 3 & 4 & 4 & 4 & 1 & Valid \\
\hline & Pernyataan sesuai dengan aspek yang ingin dicapai & 4 & 3 & 4 & 4 & 4 & 1 & Valid \\
\hline Kevalidan isi & Pernyataan mengungkapkan informasi yang benar & 4 & 4 & 4 & 4 & 4 & 1 & Valid \\
\hline $\begin{array}{c}\text { Tidak ada } \\
\text { bias }\end{array}$ & Pernyataan berisi suatu gagasan yang lengkap & 3 & 3 & 3 & 3 & 3 & 1 & Valid \\
\hline \multirow{3}{*}{$\begin{array}{c}\text { Ketepatan } \\
\text { bahasa }\end{array}$} & Bahasa yang digunakan mudah dipahami & 4 & 4 & 4 & 4 & 4 & 1 & Valid \\
\hline & Bahas a yang digunakan efektif & 4 & 4 & 4 & 4 & 4 & 1 & Valid \\
\hline & Penulisan sesuai dengan EYD & 4 & 4 & 4 & 4 & 4 & 1 & Valid \\
\hline CVI & & & & & & & 1 & \\
\hline
\end{tabular}

Ket :

$\mathrm{CVR}=$ Content Validity Ratio

$\mathrm{CVI}=$ Content Validity Index

Berdasarkan hasil validasi angket respon siswa diperoleh nilai diperoleh nilai CVI yaitu 1 sehingga dikategorikan valid untuk 5 orang validator berdasarkan kriteria minimum Lawshe $\underline{(1975)}$ untuk 5 orang validator yaitu 0,99. Setelah angket respon siswa dinyatakan valid, maka dapat digunakan untuk mengumpulkan data terkait respon siswa terhadap media pembelajaran video powtoon berbasis inkuiri terbimbing.

Tahap yang kelima yaitu revisi desain pada tahap ini, produk yang telah divalidasi akan direvisi berdasarkan komentar dan saran yang diberikan oleh validator. Oleh karena itu, ada beberapa hal yang perlu diperbaiki berdasarkan komentar dan saran dari validator yaitu sebagai berikut. 
Jurnal Mangifera Edu, Volume 6, Issue 1, July 2021, 1-19

Tabel 4. Rekapitulasi komentar dan saran dari validator

\begin{tabular}{cl}
\hline Validator & \multicolumn{1}{c}{ Komentar/Saran } \\
\hline 1 & Kesesuaian indikator pencapaian dan tujuan pembelajaran \\
& Materi harus fokus pada tujuan pembelajaran \\
& Tidak membahas yang lain selain pada cakupan indicator \\
& Tampilan tumbuhan harus dibedakan antara tumbuhan monokotil dan dikotil \\
& Tulisan pada video harus sesuaidengan PUEBI \\
& Tampilkan tahapan model pembelajaran inkuiri \\
& Warna sesuaikan, tulisan harus jelas dan suara harus jelas \\
& Pertanyaan harus tampil hingga selesai \\
& Tulisan harus tampil hingga selesai \\
& Voice over masih berjalan, tapi tampilan sudah berbeda \\
& Tulisan tertutup logo powtoon \\
& Tulisan tidak tertulis lengkap, transisi video terlalu cepat \\
& Typo hipotesis \\
& Apersepsi/motivasikurang pas \\
& Jangan pakai materi BAB Sistem Peredaran Darah \\
& Percobaan tidak tepat sasaran lebih baik disesuaikan dengan level sis wa SMP \\
& Menampilkan variasi aktivitas seperti berlari, jalan, duduk, yang berpengaruh terhadap jumlah \\
& denyut nadi \\
& Konsep tekanan terlalu melebar, harus ada konsep mengapa air bisa naik dari akar ke daun \\
& Tidak perlu menampilkan gambar pohon kelapa \& pohon manga \\
& Konsep tekanan gas tidak memfasilitasi percobaan dengan cukup jelas \\
\hline &
\end{tabular}

Tahap selanjutnya yaitu uji coba produk, menurut Puslitjacknov (2008) pada tahap uji coba produk dilakukan uji coba secara terbatas kepada 6 orang siswa kelas IX SMP Negeri 3 Pontianak. Pemilihan subjek uji coba produk secara terbatas dalam penelitian ini dilakukan dengan teknik pengambilan sampel yaitu teknik purposive sampling yang merupakan teknik dengan pertimbangan tertentu (Sugiyono, 2017). Berdasarkan hasil uji coba produk menunjukkan respon yang positif terhadap media pembelajaran video powtoon berbasis inkuiri terbimbing. Angket respon siswa terdiri dari tiga aspek yaitu kognisi, afeksi, dan konasi.

Berikut adalah hasil analisis angket respon siswa terhadap media pembelajaran video powtoon berbasis inkuiri terbimbing pada sub materi aplikasi konsep tekanan zat pada makhluk hidup. 


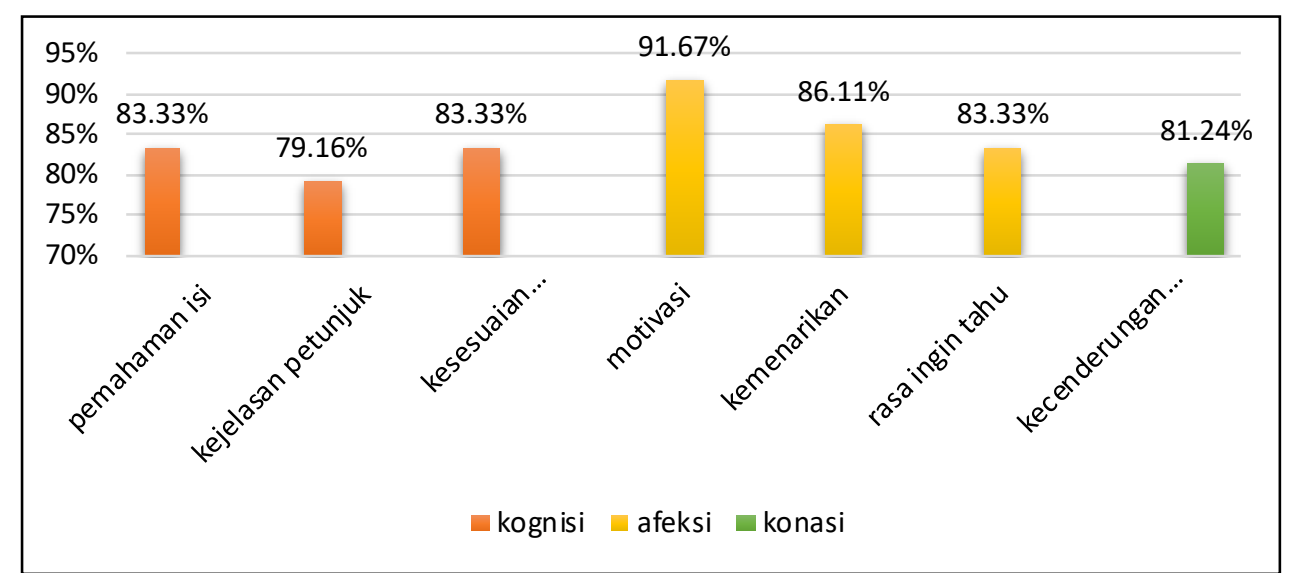

Gambar 6. Grafik respon sis wa te rhadap media pembelajaran video powtoon

Berdasarkan grafik diatas respon yang ditunjukkan oleh siswa mengarah pada respon yang bersifat positif pada aspek kognitif terdiri dari tiga indikator pertanyaan yaitu pemahaman isi memperoleh nilai rata-rata $83,33 \%$ ini dikategorikan sangat kuat. Indikator kedua yaitu kejelasan petunjuk belajar memperoleh nilai rata-rata 79,16\% ini dikategorikan kuat karena pada media video powtoon berbasis inkuiri terbimbing dilengkapi dengan tahapan model pembelajaran inkuiri terbimbing, serta indikator ketiga yaitu kesesuaian tampilan memperoleh nilai $83,33 \%$ ini dikategorikan sangat kuat, hal ini menunjukkan bahwa media pembelajaran video powtoon telah menampilkan informasi terkait dengan sub materi aplikasi konsep tekanan zat pada makhluk hidup. Sejalan dengan penelitian yang telah dilakukan oleh Qurrotaini, dkk (2020), disimpulkan bahwa media video animasi powtoon efektif digunakan sebagai salah satu media pembelajaran alternatif yang digunakan dalam pembelajaran jarak jauh. Berdasarkan hasil analisis jawaban siswa pada lembar kerja kegiatan 1 dan kegiatan 2 menunjukan rata-rata nilai lebih besar dari KKM (80). Hal ini dapat dilihat berdasarkan skor yang diperoleh siswa dalam mengerjakan lembar kerja pada google form di kegiatan 1 dan kegiatan 2 yang disajikan pada tabel berikut. 
Jurnal Mangifera Edu, Volume 6, Issue 1, July 2021, 1-19

Tabel 6. Hasil analisis jawaban sis wa pada lembar ke rja google form

\begin{tabular}{cccc}
\hline & & \multicolumn{2}{c}{ Nilai } \\
\cline { 3 - 4 } No & Kode & Kegiatan 1 & Kegiatan 2 \\
\hline 1 & R1 & 100 & 100 \\
2 & R2 & 100 & 100 \\
3 & R3 & 90 & 90 \\
4 & R4 & 80 & 90 \\
5 & R5 & 80 & 80 \\
6 & R6 & 80 & 80 \\
\hline & Rata-rata & 88,33 & 90 \\
\hline
\end{tabular}

Kemudian aspek afektif terdiri dari tiga aspek yang terdiri dari indikator motivasi memperoleh nilai rata-rata $91,76 \%$ ini dikategorikan sangat kuat dimana menunjukkan grafik motivasi yang paling tinggi diantara yang lainnya, hal ini menunjukkan bahwa media video powtoon dapat meningkatkan motivasi siswa dalam mengikuti pembelajaran. Indikator kedua yaitu kemenarikan memperoleh nilai rata-rata $86,11 \%$ ini dikategorikan sangat kuat, hal ini menunjukkan bahwa media pembelajaran video powtoon berbasis inkuiri terbimbing dapat menarik perhatian siswa, apabila siswa tertarik untuk memperhatikan sebuah media pembelajaran maka motivasi dalam mengikuti pembelajaran pun akan meningkat. Kemudian yang ketiga indikator rasa ingin tahu memperoleh nilai rata-rata 83,33\% ini dikategorikan sangat kuat, karena didalam media pembelajaran video powtoon dilengkapi dengan apersepsi yang bertujuan untuk memacu siswa rasa ingin tahu siswa terhadap materi yang akan dipelajari pada saat itu juga. Sejalan dengan penelitian yang telah dilakukan sebelumnya oleh Suhendra et al., (2016), disimpulkan bahwa terdapat perbedaan motivasi belajar antara siswa yang diajar dengan bantuan media audio-visual powtoon dan siswa yang diajar dengan konvensional.

Aspek konatif terdiri dari satu indikator yaitu kecenderungan untuk menggunakan media pembelajaran video powtoon berbasis inkuiri terbimbing memperoleh nilai rata-rata $81,24 \%$ ini dikategorikan sangat kuat. Hal ini dapat mendukung bahwa media pembelajaran video powtoon ini sangat cocok digunakan untuk pembelajaran sistem daring dengan membagikan link video dan link lembar kerja dalam bentuk google form. Hal ini tentunya didukung oleh penelitian yang telah dilakukan sebelumnya oleh Muliani \& Wibawa (2019) disimpulkan bahwa terdapat perbedaan yang signifikan terhadap hasil belajar IPA antara kelompok yang dibelajarkan dengan 
Jurnal Mangifera Edu, Volume 6, Issue 1, July 2021, 1-19

model pembelajaran inkuiri terbimbing berbantuan video dibandingkan dengan kelompok yang dibelajarkan dengan menggunakan pembelajaran konvensional.

Selain itu komentar dan saran yang diberikan siswa pun bersifat positif sehingga media pembelajaran video powtoon ini tidak perlu adanya perbaikan kembali. Hal ini menunjukkan bawah media pembelajaran video powtoon berbasis inkuri terbimbing dapat meningkatkan hasil belajar serta dapat digunakan sebagai media pembelajaran siswa SMP kelas VIII pada sub materi aplikasi konsep tekanan zat pada makhluk hidup.

\section{SIMPULAN}

Berdasarkan penelitian yang telah dilakukan didapatkan hasil validasi dengan nilai CVR dan CVI yaitu 1 (valid) karena telah memenuhi batas minumun Lawshe untuk kategori 5 orang validator dengan nilai minimum CVR dan CVI sebesar 0,99 maka dapat disimpulkan bahwa media pembelajaran video powtoon berbasis inkuiri terbimbing pada sub materi aplikasi konsep tekanan zat pada makhluk hidup dinyatakan layak digunakan sebagai media pembelajaran di sekolah, serta respon yang diberikan siswa sangat positif dengan nilai secara keseluruhan $83,85 \%$ pada uji coba produk terhadap media pembelajaran video powtoon berbasis inkuiri terbimbing termasuk dalam kategorikan sangat kuat.

\section{DAFTAR PUSTAKA}

Ali, M dan M. Asrori. (2008). Psikologi Remaja: Perkembangan Peserta Didik. Jakarta: Bumi Aksara.

Almuntasheri, S. Gillies, R.M. Wright, T. (2016). The Effectiveness of a Guided Inquiry-based, Teachers' Professional Development Programme on Saudi Students' Understanding of Density. Science Education International, 1(27), 33-34.

Anggareni, N.W. Ristiati, N.P. Widiyanti, N.L.P.M. (2013). Implementasi Strategi Pembelajaran Inkuiri Terhadap Kemampuan Berpikir Kritis dan Pemahaman Konsep IPA Siswa SMP. e-Journal Program Pascasarjana Universitas Pendidikan Ganesha. 3(1).

Arikunto, S. (2013). Prosedur Penelitian: Suatu Pendekatan Praktik. Jakarta: Rineka Cipta.

Arsyad, Azhar. (2013). Media Pembelajaran. Jakarta : Rajawalli Pers. 
Jurnal Mangifera Edu, Volume 6, Issue 1, July 2021, 1-19

Borg, W. R. and M. D. Gall. (1989). Educational Research: An Introduction. Fifth Edition. New York and London: Longman.

Delviana, Evi. (2017). Aplikasi Powtoon Sebagai Media Pembelajaran: Manfaat Dan Problematikanya. Prosiding Seminar Nasional Dies Natalis Ke-56 Universitas Negeri Makassar. Jakarta: 30 Oktober, 2019. Hal. 1-6.

Dewi, N, L. Dantes, N. Sadia, W, I. (2013). Pengaruh Model Pembelajaran Inkuiri Terbimbing Terhadap Sikap Ilmiah Dan Hasil Belajar IPA. Journal of Education Technology, 3(1), 1521.

Diyantini, M.N. Saudnyana, N.I. Ardana, K.I. (2017). Pengaruh Model Pembelajaran Inkuiri Terbimbing Berbantuan Media Audio-Visual Terhadap Kompetensi Pengetahuan IPA Siswa Kelas V. E-Journal PGSD Universitas Pendidikan Ganesha Mimbar PGSD, 5(2), 110.

Hamdayama, Jumanta. (2014). Model Dan Metode Pembelajaran Kreatif Dan Berkarakter. Bogor : Ghalia Indonesia.

Haryani, D. Pujiastuti, H. (2020). The Science Literacy Capabilities Profile Using Guided Inquiry Learning Models. JPPPF (Jurnal Penelitian dan Pengembangan Pendidikan Fisika), 6(1), 81-88.

Herawati, R. Sulisworo, D. Fayanto, S. (2019). The Development of Learning Videos on PowToon-based Work and Energy Topics to Support Flipped Classroom Learning. IOSR Journal of Research \& Method in Education, 4(9), 51-58.

Irmayanti, Rima. (2019). Perencanaan Karier Pada Peserta Didik SMP. Quanta, 3(1), 1-6.

Iswatun, I. Mosik, M. Subali, Bambang. (2017). Penerapan Model Pembelajaran Inkuiri Terbimbing untuk Meningkatkan KPS dan Hasil Belajar Siswa SMP Kelas VIII. Jurnal Inovasi Pendidikan IPA, 3(2), 150-160.

Jack, G,U. (2013). Concept Mapping and Guided Inquiry as Effective Techniques for Teaching Difficult Concepts in Chemistry: Effect on Students'Academic Achievement. Journal of Education and Practice, 5(4), 9-15.

Lawshe, C.H. (1975). Quantitative Approach to Content Validity. Journal of Personnel Physicology. 563-575.

Listyawati, muji. (2012). Pengembangan perangkat pembelajaran IPA terpadu di SMP. Jurnal Of Innovative Science Education, 1(1), 61-69. 
Jurnal Mangifera Edu, Volume 6, Issue 1, July 2021, 1-19

Marlena, N. Dwijayanti, R. Patrikha, F.D. Parjono. Sudarwanto, T. (2018). Penyegaran Kemampuan Guru Dalam Merancang Media Pembelajaran Melalui Aplikasi Powtoon dan Screen O Matic. Jurnal Pemberdayaan Masyarakat Madani, 2(2), 202-223.

Muliani, N.K.D. Wibawa, I.M.C. (2019). Pengaruh Model Pembelajaran Inkuiri Terbimbing Berbantuan Video Terhadap Hasil Belajar IPA. Jurnal Ilmiah Sekolah Dasar, 3(1), 107119.

Mulyana, S. Rusdi. Vivanti, D. (2018). The Effect Of Guided Inquiry Learning Model And Scientific Performance On Student Learning Outcomes. Indonesian Journal of Science and Education, 2(1), 105-109.

Puslitjaknov. (2008). Metode Penelitian Pengembangan. Departemen Pendidikan Nasional.

Purwanti, Y.K. Suryani, Ela. (2018). Pengaruh Discovery Learning Dengan Pendekatan Scientific Berbantuan Powtoon Terhadap Motivasi Dan Kemampuan Berpikir Kritis. Jurnal $U N W, 1(1)$.

Puspitarini, D.Y. Akhyar, M. Djono. (2018). Developing Powtoon-Based Video Learning Media for Five Grade Students of Elementary School. Advances in Social Science, Education and Humanities Research, 165, 173-177.

Qurrotaini. Dkk. (2020). Efektivitas Penggunaan Media Video Berbasis Powtoon Dalam Pembelajaran Daring. Prosiding Seminar Nasional Penelitian Lppm Umj. Jakarta: 7 Oktober 2020. Hal. 1-7.

Riduwan. (2015). Skala Pengukuran Variabel-Variabel Penelitian. Bandung : Alfabeta.

Saihu. (2019). Komunikasi Pendidik Terhadap Anak Berkebutuhan Khusus Di Sekolah Khusus Asy-Syifa Larangan. Jurnal Pendidikan Islam, 1(3), 418-440.

Sugiman. Sumardyono. Marfuah. (2016). Guru Pembelajar Modul Matematika SMP Kelompok Kompetensi A Karakteristik Siswa SMP dan Bilangan. Jakarta : Kemendikbud.

Suhendra, Iin. Enawaty, Eny. Amalia Melati, Husna. (2018). Pengaruh Penggunaan Media Audiovisual Powtoon Terhadap Motivasi Dan Hasil Belajar Siswa Materi Unsur Senyawa Campuran. Jurnal Pendidikan dan Pembelajaran, 7(3), 1-8.

Sudjana, Nana. Rivai, Ahmad. (2013). Media Pengajaran. Bandung : Sinar Baru Algensindo.

Sugiyono. (2015). Metode Penelitian Kombinasi (Mix Methods). Bandung: Alfabeta. 
Jurnal Mangifera Edu, Volume 6, Issue 1, July 2021, 1-19

Sugiyono. (2017). Metode penelitian kuantitatif,kualitatif, dan R\&D. Bandung: Alfabeta.

Syafitri, Dwi. Nevrita. Asikin, Nurul. (2019). Penggunaan Multimedia Berbasis Powtoon Materi Sistem Pernapasan Manusia Kelas VIII Dikaji Dari Aspek Validitas. Artikel Ilmiah Biologi. 9 November 2019. http://repository.umrah.ac.id/ 3849.

Wardani, S. Nurhayati, S. Safitri, A. (2016). The Effectiveness of the Guided Inquiry Learning Module towards Students' Character and Concept Understanding. International Journal of Science and Research (IJSR), 6(5), 1589-1594.

Wulanningsih, S. Prayitno, B, A. Probosar, R, M. (2012). Pengaruh Model Pembelajaran Inkuiri Terbimbing Terhadap Keterampilan Proses Sains Ditinjau Dari Kemampuan Akademik Siswa SMA Negeri 5 Surakarta. Pendidikan Biologi, 4(2), 33-43. 